\title{
The Role of Remuneration Contribution and Social Support in Organizational Life to Build Work Engagement
}

\author{
Fauchil Werdati \\ Chulalongkorn University, Thailand \\ Didit Darmawan \\ Nikmah Rochmatin Solihah \\ Mayjen Sungkono University
}

\begin{abstract}
Abtract
The increasingly diverse levels of human needs along with the high intensity causes them to need regular income in a large amount. These demands can make someone change work to earn a higher income. For companies, the phenomenon of employees who often changes work becomes a problem because of the high intensity of employee turnover can affect company productivity. The human resources department needs to learn more specifically about employee work engagement to prevent employees from leaving a job. The growing sense of employee engagement can be supported by many factors. This study aims to analyze and find out and describe the effects of remuneration and social support on work engagement. The population in this study were all employees of PT Mega Multi Spring with 80 respondents taken based on a purposive sampling technique. This study uses primary data in the form of respondents' responses to variables using a questionnaire. The analytical tool used is linear regression. The results showed that remuneration had a significant positive effect on work engagement. In addition it was also found that social support had a significantly positive effect on work engagement. In the end remuneration and social support variables have a significant simultaneous effect on work engagement. From the results of the study it can be concluded that proper remuneration and positive social support make employees have a sense of attachment to work.
\end{abstract}

Key words : Remuneration, Social Support, WorkEngagement

\section{INTRODUCTION}

The level of economic growth of a country is an indicator of economic development towards a better condition. A country's economy has grown when the level of economic activity is higher than that achieved in the earlier period. At present Indonesia is experiencing promising economic growth. Economic growth in Indonesia is characterized by the development of industrial sectors that innovate with a variety of products.Competition also occurs in every industry that grows. Competition in the industrial sector is a problem for the community because it results in a variety of product offerings and this increases interest in higher consumption. One way to solve this problem is that someone must have a high income in accordance with their needs.

To get a high income someone will find a job with a salary that suits their wants and needs. Not infrequently someone often changes jobs because they have not found a job with an appropriate salary. Satisfaction with salary is when someone's perception of salary is in accordance with what is obtained (Lum et al., 1998). Someone will stop to change jobs when that person has received a salary as expected and is able to meet all his life needs. The phenomenon of employees who often change work certainly becomes a threat to the company because it results in losses. The high level of turnover makes the company experience a decrease in productivity. Mathis and Jackson (2004) state that one of the biggest losses when a turnover is the cost. The condition of employee turnover causes the company to bear costs for employee replacement in the form of new employee recruitment costs, training costs, productivity costs, and dismissal costs. 
The challenge for companies is how to influence employees to stay on the job to prevent turnover and decrease productivity. The human resources department needs to learn more specifically about work engagement. Employees who have a work attachment are likely to survive in a job. Hughes and Rog (2008) stated that work attachment is a high emotional and intellectual relationship that employees have towards their work, organization, manager, or coworkers who give influence to add the best contribution to their work. Employees are important assets for the company, their functions and roles are needed to achieve the vision and mission and produce added value for the company. For that the company must be sensitive to the things that can affect employees to survive in their work. Dessler (2017) states that companies must develop a comprehensive approach to retaining employees through efforts to strengthen employee engagement. This is done with the existence of a fair remuneration system accompanied by the role of social support in organizational life.

The objectivity of the remuneration system is one cause that can influence employees to have a sense of work engagement. Sikula (1981) stated that remuneration is a gift, payment or repayment for services that have been provided. Remuneration is given to employees and arises from their work in the form of payments or gifts (Dessler, 2017). Remuneration affects employee work engagement because the purpose of remuneration is to increase employee welfare, provide employee motivation and increase employee loyalty (Darmawan, 2019). With remuneration given according to contribution, employees will feel satisfied and foster a sense of attachment to work. Employees often change jobs because they have not found rewards in the form of satisfying welfare guarantees. The right remuneration system causes a person to stay as an employee but vice versa an improper remuneration system causes the employee's disinterest to stay in the organization.

Another factor that can affect work engagement is social support. Social support is a form of positive help from the surrounding environment in the form of a conducive work environment and good colleague relations. Positive social support will make employees feel comfortable when working. At work, social support can come from companies and coworkers while support from outside the workplace comes from family and friends (Lysaght and Trode, 2008). Employees who work comfortably will have work attachments and can focus while working to produce optimal output for the company. Conversely employees who work without comfort will be less focused and not optimal when working.

PT Mega Multi Pegas is a manufacturing company that engages in automotive manufacturing of automobile spare parts in the form of leaf springs. Leaf spring (leaf spring) is part of the car's suspension system that functions as a vehicle load holder. The process of making leaf springs requires special skills and is carried out by employees who have been trained and given direction. The whole process is carried out using machines so that not all employees can operate different machines in each section. In certain parts such as engenering and quality control must be done by skilled employees because the process determines the quality of the leaf spring products produced. The high level of complexity of the production process results in employees becoming easily bored. Employees need positive social support from the work environment to avoid stress and burnout. The complexity of the production process also makes employees want appropriate rewards in the form of guaranteed remuneration and welfare. When these two things are fulfilled indirectly it will make employees have a loyalty and work attachment to the company.

From the earlier explanation it can be stated that the amount of remuneration given to employees and positive social support will affect employee work loyalty. Employees who work with loyalty indirectly have an attachment to work. Based on the previous description, the title of the research is determined as The Role of Remuneration Contribution and Social Support in Organizational Life to Build Work Engagement. The objectives in this research are as follows: (1) to analyze the effect of remuneration on work engagement? (2) to analyze the effect of social support on work engagement? (3) to analyze the simultaneous effect of remuneration and social support on work engagement?

\section{Remuneration}

\section{LITERATURE REVIEW}


Remuneration is an important thing for employees and the company. Milkovich and Newman (2002) stated that all forms of things received with all forms of real money and services as well as benefits received by employees as a tangible manifestation of work relations. For companies, remuneration is defined as an act of retribution or compensation received by employees from the company for the achievements given by workers to realize company goals (Pora, 2011). Dessler (2017) states that remuneration is any form of payment compensation given to employees and arising from their work.

The remuneration indicators stated by Pora (2011) include (1) salary, (2) benefits, (3) bonuses and commissions, (4) fixed benefits and non-permanent benefits. Mondy and Noe (2010) state that remuneration is not only related to financial factors but also includes non-financial factors such as interesting tasks; job challenges; opportunities for recognition; opportunities for promotion; pleasant coworkers; comfortable working environment conditions; sound policy; recognition of status symbols; and flexible working time. Smith and Nel (2010) state that the remuneration indicator consists of three principles as follows: (1) conformity, namely the remuneration obtained by employees in accordance with the contribution made to the company; (2) fairness means the level of remuneration given to employees must be by the burden and work performance; and (3) effectiveness is the purchase of remuneration in accordance with regulations and is given in harmony with the long-term value and health of the company. Based on the factors that compose remuneration can be expressed as total financial and non-financial compensation received by employees in return for work that has been given to the company so that employees are more prosperous and comfortable in working.

\section{Social Support}

Cobb (1976) describes social support as information that directs a person to believe that the environment cares and appreciates it. Shumaker and Brownell (1984) argue that social support leads to an increase in one's well-being caused by the exchange of resources. Leavy (1983) states the concept of social support as a quality mutual help relationship. This quality refers to the strength and closeness of the relationship between two or more people. Social support at work can be seen as a relationship between employees who help each other and give a feeling of caring. Cohen and Wills (1985) state that when the quality of the relationship is high indirectly employees are given psychological and mental resources. Therefore, social support, can be seen as one of the work resources as mentioned in the work-demand resource model (Bakker and Demerouti, 2007).

Smet (1994) and Sinokki (2011) stated that forming social support variables include emotional, judgment, information, and instrumental support while Crider (1983) stated social support has three components. The three components are: (1) emotional attention, that is, individuals feel cared about by people around and help solve problems, (2) information is individuals get needed information and can convey information to other people, (3) assessment is giving attention, encouragement, feedback, or supportive assessment of the work done.

Based on the earlier description it can be stated coverage of social support variables. Social support is an attitude of mutual help between two or more people who has a positive effect and a happy feeling in the form of support and attention. Thus social support in the form of interpersonal relationships with people around in the form of empathy provided through the process of communication and social contact and reciprocal relationships that can strengthen social relationships.

\section{Work Engagement}

The concept of work engagement was first coined by William Kahn in 1990. Kahn (1990) described work engagement as utilizing organizational or individual members who were fully physically, cognitive and emotionally connected to their work. Work engagement according to Wellins et al. (2010) is also defined as the extent to which employees are committed to something or someone in an organization, and how long they stay as a result of employee commitment and loyalty because they want to continue working in the organization. Schaufeli and Bakker (2004) revealed that work engagement is a relationship to active and positive work that is characterized 
by enthusiasm, dedication and absorption. According to Bakker et al. (2011) the driving factor of work engagement comes from the work environment and the individual personal. Thomas (2009) described work engagement as the level of someone actively having self-management to carry out a job. Robbins and Judge (2008) stated work engagement is the involvement, satisfaction and enthusiasm of individuals with the work they do.

Work engagement leads to the level of fulfillment of employee needs such as the basic needs of an employee; management support for the organization where the employee works; the employee's need to feel that he is accepted by the organization; and employees can learn and grow and develop (Fleming and Asplund, 2007). Schaufeli et al. (2002) states involvement is characterized by three dimensions as follows: (1) strength which is the courage to try hard to complete a job, and persevering to face difficulties when working, (2) dedication is a strong sense of involvement in a job and foster enthusiasm, pride, inspiration, and challenge, (3) absorption is the level of concentration and seriousness of a job so that when working time feels like it passes by so quickly and completes work effectively. The existence of work attachment makes employees a quality resource and helps to increase company productivity. Likewise Schiemann (2009) states the same thing.

Thus work engagement is a feeling of pride to be a member of the company which is shown by the attitude of loyalty towards their work in terms of time and energy and strive to be able to complete the work to the maximum. The driving factor for the emergence of work attachment stems from the individual himself. One example of a motivating factor is having knowledge of the details of the job so that it indicates that the individual is involved with his work. As for factors from the source of work, this is related to the work environment and the work itself from the organization to coworkers. The situation and condition of the organization can affect individual work engagement.

\section{Conceptual Framework for Research}

From the results of research by Mokaya and Kipyegon (2014); Yin (2017) and Shantz et al. (2013) stated that remuneration had a significant effect on work engagement. Remuneration is a contributor that is quite high influence on work engagement. Hoole and Hotz (2016) in their research also stated that remuneration is an important motivator to foster employee engagement.

Research by Ramos and Almeida (2017); Wang and Eccles (2012); Abhijit and Debalina (2010); Bakker (2011); Schaufeli et al. (2009) show that social support increases work engagement. Good working environment relations will encourage employees to have attachment to work. Based on the description of the previous research, a research will be conducted which will examine whether remuneration and social support simultaneously influence employee work engagement as shown in the following figure.

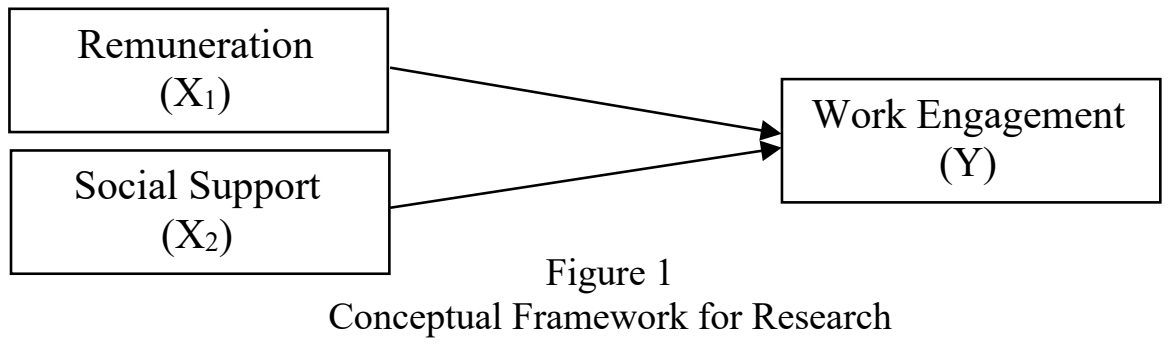

According to Gravetter and Forzano (2012) the hypothesis is a statement that describes or explains the variables proposed to be tested and evaluated. Based on the conceptual framework in Figure 1, the following hypotheses can be concluded: (a) remuneration has a significant effect on employee work engagement; (b) social support has a significant effect on employee work engagement; (c) remuneration and social support have a significant simultaneous effect on employee work engagement. 


\section{RESEARCH METHOD}

This study uses a quantitative descriptive approach to the type of explanatory research. The type of data used is primary data in the form of questionnaires and interviews and secondary data in the form of information from various other sources such as the internet and books. Questionnaires were distributed to employees of PT Mega Multi Pegas while the interview method was the process of obtaining information through question and answer (two-way communication) of several employees of PT Mega Multi Pegas. The scale used in this study is the Likert scale.

This research uses purposive sampling technique to get the sample as expected. Based on primary data the number of employees of PT Mega Multi Pegas is 84 people. The number of respondents obtained was 80 samples with criteria, namely; 1) PT Mega Multi Pegas employees; 2) willing to fill out questionnaires distributed by researchers; 3 ) minimum sample $50 \%$ of the total population. This research consists of two independent variables and one dependent variable. The first independent variable is remuneration and the second independent variable is social support while the dependent variable is work engagement.

Remuneration is defined as the total compensation received by employees of PT Mega Multi Pegas in return for work that has been given to the company in the form of money, benefits or other welfare benefits. This study uses indicators according to Smith and Nel (2010) which state that the remuneration policy must include three basic principles as follows: (1) conformity, namely the remuneration that employees get according to the contribution made to the company; (2) fairness means the level of remuneration given to employees must be in accordance with the burden and work performance; (3) effectiveness is the purchase of remuneration in accordance with the regulations and is given in harmony with the long-term value and health of the company. Therefore the remuneration of employees at PT Mega Multi Pegas is planned well so that it is in line with the employee's expectations so that it causes work engagement.

Social support is an attitude of mutual assistance between two or more people that has a positive effect and a happy feeling in the form of support and attention. In this study the authors use social support indicators according to Crider (1983) social support has three components as follows: (1) emotional attention, namely individuals feel cared about by people around and help to solve problems; (2) information is an individual obtaining required information and can convey information to other people; (3) assessment is giving attention, encouragement, feedback, or supportive assessment of the work performed. Positive social support will help PT Mega Multi Pegas employees feel comfortable so they have work engagement.

Work engagement is the attitude and behavior of employees when working by expressing themselves totally to the company. The employee feels proud to be part of the organization where he works, and goes the extra mile in terms of time and energy to achieve the overall vision and mission of the organization. According to Schaufeli et al. (2002) involvement is characterized by three dimensions as follows: (1) strength which is the courage to try as hard as possible to complete a job, and diligently face difficulties when working, (2) dedication is a strong sense of involvement in a job and foster enthusiasm, pride , inspiration, and challenges, (3) absorption is the level of concentration and seriousness of a job so that when working time feels like it passes by so quickly and finish the job effectively. The existence of work attachment makes employees a quality resource and helps to increase company productivity.

The analytical tool used in this study is multiple linear regression analysis. To test the quality of the data used the reliability and validity test. Before conducting the regression process, first do the classical assumption test which consists of a normality test, an autocorrelation test, a heteroscedasticity test, and a multicollinearity test. Hypothesis testing consists of the $t$ test and the $F$ test.

\section{Profile of Respondents}

\section{RESULTS AND DISCUSSION}

From the results of data collection obtained as many as 80 respondents. Table 1 shows the profile of the respondents. 
Tabel 1

Profil Responden

\begin{tabular}{|c|c|c|c|c|c|c|c|c|c|}
\hline Gend & \multicolumn{10}{c|}{ Age } \\
\cline { 2 - 10 } & $21-$ & $26-$ & $31-$ & $36-$ & $41-$ & $46-$ & $51-$ & $\begin{array}{c}\text { Frequen } \\
\text { cy }\end{array}$ & $\begin{array}{c}\text { Percenta } \\
\text { ge }\end{array}$ \\
\hline Male & 5 & 19 & 6 & 14 & 6 & 5 & 6 & 61 & $76,3 \%$ \\
\hline $\begin{array}{c}\text { Femal } \\
\text { e }\end{array}$ & 14 & 2 & 1 & 0 & 1 & 1 & 0 & 19 & $23,8 \%$ \\
\hline \multicolumn{19}{|c|}{ Total } \\
\hline
\end{tabular}

Source: SPSS output and processed by the author

Samples obtained from PT Mega Multi Pegas totaled 80 people with details of 61 men and 19 women. PT Mega Multi Pegas's total employees are dominated by male employees with an age range of 26 to 30 years, amounting to 19 people while the number of female employees is dominated by ages 21 to 25 years with a total of 14 people. PT Mega Multi Pegas's employees are dominated by male employees because to produce leaf springs requires strong physical and energy. All employees of PT Mega Multi Pegas are of productive age but there are six male employees who are nearing retirement because they are over 52 years old. In accordance with company regulations the six employees must be retired because their productivity to produce leaf spring is starting to decrease. Therefore the company must prepare a remuneration in the form of pension in accordance with government regulations and employee contributions while working.

\section{Validity Test}

To test the validity of the instruments in this study, a validity test was conducted. According to Hair et al. (2010) factor loadings \pm 0.3 to 0.4 are minimally acceptable so to know the validity of a statement from each instrument must have a greater load of 0.3 .

Table 2

Validity Test

\begin{tabular}{|c|c|c|c|c|}
\hline No & Variables & Statement Topics & $\begin{array}{l}\text { Corrected } \\
\text { item- total } \\
\text { correlation }\end{array}$ & Status \\
\hline \multirow{7}{*}{1.} & \multirow{7}{*}{$\begin{array}{l}\text { Remuneration } \\
\text { (X1) }\end{array}$} & $\begin{array}{l}\text { Salary acquisition is in accordance with } \\
\text { minimum wage provisions }\end{array}$ & 0,508 & Valid \\
\hline & & Salary acquisition according to position & 0,657 & Valid \\
\hline & & Salaries exceed the minimum wage requirement & 0,461 & Valid \\
\hline & & Salary acquisition according to education & 0,618 & Valid \\
\hline & & $\begin{array}{l}\text { Salary acquisition according to government } \\
\text { regulations }\end{array}$ & 0,796 & Valid \\
\hline & & Obtaining position allowances & 0,487 & Valid \\
\hline & & Obtaining health benefits & 0,691 & Valid \\
\hline \multirow{5}{*}{2.} & \multirow{5}{*}{$\begin{array}{l}\text { Social } \\
\text { Support } \\
\text { (X2) }\end{array}$} & Ability to work with colleagues & 0,489 & Valid \\
\hline & & Help coworkers when there are problems & 0,853 & Valid \\
\hline & & Willingness to help coworkers when in trouble & 0,814 & Valid \\
\hline & & Share information about work. & 0,780 & Valid \\
\hline & & Coworkers support with his attitude & 0,787 & Valid \\
\hline \multirow{5}{*}{3.} & \multirow{5}{*}{$\begin{array}{c}\text { Work } \\
\text { Engagement } \\
\text { (Y) }\end{array}$} & Glad to be an employee & 0,849 & Valid \\
\hline & & Proud to be an employee & 0,787 & Valid \\
\hline & & Enthusiasm at work & 0,877 & Valid \\
\hline & & Keiginan finished the job well & 0,846 & Valid \\
\hline & & The habit of getting work done on time & 0,856 & Valid \\
\hline
\end{tabular}




\begin{tabular}{|l|l|c|c|}
\hline & $\begin{array}{l}\text { Efforts to find solutions to overcome work } \\
\text { constraints }\end{array}$ & 0,856 & Valid \\
\cline { 3 - 4 } & Concentrate when working & 0,865 & Valid \\
\cline { 3 - 4 } & A sense of responsibility towards work & 0,864 & Valid \\
\cline { 2 - 4 } & A sense of responsibility for product quality & 0,801 & Valid \\
\hline
\end{tabular}

Source: SPSS output and processed by the author

Based on the validity test table it can be seen that each instrument in this study has a total correlation value greater than 0.3 and a positive value. It can be concluded that each question from all indicators in this study passed the Validity Test and was declared Valid.

\section{Reliability Test}

To measure reliability using the Cronbach alpha statistical test. The reliability scale of all instruments was considered reliable if the average $r$ value was 0.6 with an acceptable coefficient for research but not important for diagnostic purposes because of misdiagnosis and frequency should be included if needed for diagnostic purposes (Ritacco and Suffla, 2012). The reliability test results in table 3 show that the alpha coefficient values of each variable studied showed mixed results. All statement items of remuneration, social support, and work engagement variables have Alpha coefficients $>0.60$. Thus it can be concluded that the measuring instrument used in this study is reliable.

Table3

Reliability Test

\begin{tabular}{|c|l|c|c|c|}
\hline No & \multicolumn{1}{|c|}{ Variables } & Cronbach's Alpha & Alpha Standard & Status \\
\hline 1. & Remuneration (X1) & 0,834 & 0,600 & Reliable \\
\hline 2. & Social Support (X2) & 0,885 & 0,600 & Reliable \\
\hline 3. & Work Engagement (Y) & 0,962 & 0,600 & Reliable \\
\hline
\end{tabular}

Source: SPSS output and processed by the author

\section{Classic Assumption Test}

Gujarati and Porter (2013) state that the classic assumption test is carried out with the aim of ensuring whether the research results are valid or not. The first classic assumption test is the normality test. According to Gujarati and Porter (2013), the normality test aims to determine the distribution of normal residual values or not.

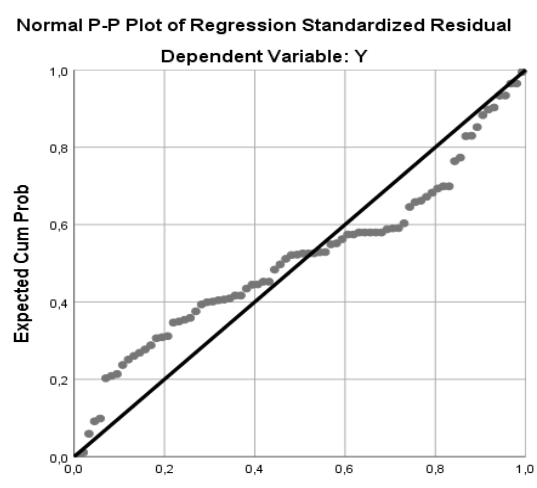

Piguremcem Prob

Normal Probability Plot

Source: SPSS output

Figure 2 shows the results of the normality test calculation using the normal probability plot graph. Based on the graphic image, the points spread around the diagonal line and the distribution follows 
the direction of the diagonal line so that it can be stated that the regression model has fulfilled the normality assumption.

The existence of residual values in a study that does not have a constant variant results in heteroscedasticity (Gujarati and Porter, 2013). Heteroscedasticity is one of the deviations of assumptions about the similarity of variants. Based on Figure 3 Heterokedastisitas test results show that the points spread randomly and spread both above and below the number 0 on the $\mathrm{Y}$ axis so that there is no heterokedasticity in the regression model.

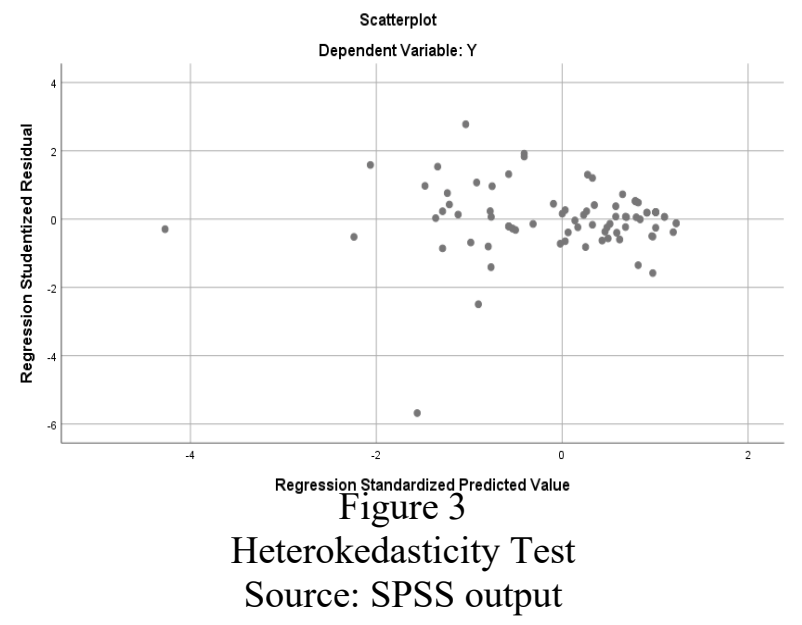

Next up is the autocorrelation test. According to Gujarati (2004) autocorrelation test is a correlation between the members of the observation sorted according to time and space. Based on the SPSS output it can be stated that there is no autocorrelation problem because the DurbinWatson value shows a number below 2 which is 1.728 thus there is no autocorrelation problem.

According to Gujarati (2004) multicollinity is a linear relationship between independent variables that can be tested by calculating VIF values. The calculation requirement is that if VIF $<10$ then the independent variables do not have a linear relationship. The calculation results of Table 4 show that there are no independent variables that have a tolerance value of more than 0.1 , which means there is no correlation between the remuneration and social support variables. And the results of the calculation of the value of variance inflation factor (VIF) indicate that the two independent variables have a VIF value $<10$ and it shows no symptoms of multicollinearity among the independent variables in the regression model.

\section{t Test}

According to Gujarati and Porter (2013), the significance test is to test whether or not the results of a hypothesis. Hypothesis testing using statistical $t$ test aims to determine the effect of partial independent variables on the dependent variable. From Table 4 it can be seen that partially the remuneration and social support variables have a significant effect on work engagement with the $\mathrm{P}$ value of Sig. $0,000<0.05$.

Table4

Coefficients $^{\mathrm{a}}$

\begin{tabular}{|c|c|c|c|c|c|c|c|c|}
\hline & \multirow{2}{*}{ Model } & \multicolumn{2}{|c|}{$\begin{array}{c}\text { Unstandardized } \\
\text { Coefficients }\end{array}$} & \multirow{2}{*}{$\begin{array}{c}\begin{array}{c}\text { Standardized } \\
\text { Coefficients }\end{array} \\
\text { Beta }\end{array}$} & \multirow{2}{*}{$\mathrm{t}$} & \multirow{2}{*}{ Sig. } & \multicolumn{2}{|c|}{$\begin{array}{l}\text { Collinearity } \\
\text { Statistics }\end{array}$} \\
\hline & & B & $\begin{array}{l}\text { Std. } \\
\text { Error }\end{array}$ & & & & Tolerance & VIF \\
\hline \multirow[t]{2}{*}{1} & (Constant) & 3,212 & 4,570 & & ,703 & ,484 & & \\
\hline & $\mathrm{X} 1$ & ,304 & ,080 & ,280 & 3,806 & ,000 & ,758 & 1,319 \\
\hline
\end{tabular}




\begin{tabular}{|l|l|l|l|l|l|l|l|}
$\mathrm{X} 2$ & 1,314 &, 148 &, 653 & 8,881 &, 000 &, 758 & 1,319 \\
\hline
\end{tabular}

Source: SPSS output

\section{F Test}

F statistical test is used to show the simultaneous effect of independent variables on the dependent variable. Significant means the relationship that occurs can apply to the population (Gujarati and Porter, 2013). Based on Table 5 shows that a significant value of $0.00<0.05$. The conclusion is that the independent variable has a significant effect simultaneously on the dependent variable.

Table 5

ANOVA $^{\mathrm{a}}$

\begin{tabular}{|c|l|c|c|c|c|c|}
\hline \multicolumn{2}{|c|}{ Model } & $\begin{array}{c}\text { Sum of } \\
\text { Squares }\end{array}$ & df & $\begin{array}{c}\text { Mean } \\
\text { Square }\end{array}$ & F & Sig. \\
\hline \multirow{2}{*}{1} & Regression & 7363,27 & 2 & 3681,635 & 83,513 &, $000^{\mathrm{b}}$ \\
\cline { 2 - 7 } & Residual & 3394,53 & 77 & 44,085 & & \\
\cline { 2 - 7 } & Total & 10757,8 & 79 & & & \\
\hline
\end{tabular}

Source: SPSS output

\section{Regression Equation}

Regression analysis is used to measure the dependency between the independent variable and the dependent variable in order to predict the average value of the dependent variable based on the value of the known independent variable (Gujarati, 2004). Based on the calculations in Table 4 , the regression equation is obtained as follows:

$\mathrm{Y}=3,212+0,304 \mathrm{X} 1+1,314 \mathrm{X} 2+\mathrm{e}$

\section{Determinant Coefficient $\left(\mathbf{R}^{2}\right)$}

According to Gujarati and Porter (2013) the determinant coefficient is a measure used to see how much influence the independent variable has on the dependent variable. The level of accuracy of the regression is determined by the value of $\mathrm{R} 2$. The more $\mathrm{R} 2$ value approaching 1 , it can explain well the effect of the independent variable on the dependent variable.

Table6

Model Summary ${ }^{\mathrm{b}}$

\begin{tabular}{|c|c|c|c|c|c|}
\hline Model & $\mathrm{R}$ & $\mathrm{R}$ Square & $\begin{array}{c}\text { Adjusted R } \\
\text { Square }\end{array}$ & $\begin{array}{c}\text { Std. Error of the } \\
\text { Estimate }\end{array}$ & Durbin-Watson \\
\hline 1 & $0,827^{\mathrm{a}}$ & 0,684 & 0,676 & 6,640 & 1,728 \\
\hline
\end{tabular}

Source: SPSS output

The results of the correlation calculation (R) show a value of 0.872 which is almost close to +1 so that it can be interpreted the relationship between remuneration variables and social support for work engagement is very strong. The calculation result of R Square (R2) shows a value of 0.684 so that $68.4 \%$ of the remuneration and social support variables are able to explain the ups and downs of work attachment while the remaining $31.6 \%$ is influenced by other variables not yet examined.

\section{Discussion}

Based on the description of the results of research that has been done, it can be seen that remuneration and social support have a significant positive effect on work engagement. The results of the first hypothesis prove that remuneration has a significant effect on work engagement. These results are in accordance with previous studies (Shantzet et al., 2013; Mokaya 
and Kipyegon, 2014; Hoole and Hotz, 2016; Yin, 2017). Remuneration to increase work engagement is one of management practices to achieve the ultimate goal of triggering employee performance (Calvin, 2017). One component of remuneration is conformity and fairness. Remuneration is given to employees based on performance appraisal. Providing fair and open remuneration will create a conducive working atmosphere. Companies need to learn and understand the desires of employees about remuneration that suits their needs. This is consistent with the previous statement that the total traditional awards are no longer attractive and suitable now (Lyons and Ben-Ora, 2002; Heneman and Coyne, 2007). Companies can influence work engagement by paying attention to the remuneration system provided to employees. The correct remuneration system if implemented contains elements of justice and proportionality. The appropriate form of remuneration meets employee welfare, namely incentives, compensation, holiday benefits, health care benefits for employees and family members, old age benefits. Employee productivity will increase if their welfare is met. Prosperous employees have a strong attachment to their work and organization (Darmawan, 2019).

The results of the second hypothesis prove that social support has a significant positive effect on work engagement. These results are in accordance with previous studies (Schaufeli et al., 2009; Abhijit and Debalina 2010; Bakker, 2011; Wang and Eccles, 2012; Ramos and Almeida, 2017). Social support makes it easy for employees to get work done, provides emotional support when stressed, and influences employees to have attachment to work. As revealed by Bakker (2009), employees who get a positive influence will become more productive. Support received from companies and coworkers can be a source for motivation to foster work engagement and improve employee performance (Schaufeli and Bakker, 2004; Xanthopoulou et al., 2008; Putra et al., 2019; Sinambela et al., 2019) and sources job satisfaction for employees (Al Hakim et al., 2019). The company can help create social support for employees. Company support is very important to encourage the growth of work engagement and reduce employee workload (Wayne et al., 1997).

\section{CONCLUSIONS AND RECOMMENDATIONS}

This study shows the effect of each variable and social support on work engagement. From the results of research and data processing and discussion, conclusions can be drawn to answer the research objectives, namely: (1) remuneration has a significant effect on work engagement; (2) social support has a significant effect on work engagement; (3) remuneration and social support have a significant simultaneous effect on work engagement.

From the results of research that has been done with some limitations, suggestions that can be given by the author for further research include: (1) PT Mega Multi Spring is expected to be able to develop a better remuneration system with the principle of a balance between employee rights and obligations. Employees want to feel comfortable and proud of their company. In addition, employees want to be valued for what they know and for what they produce in the form of performance. Therefore their rights need to be fulfilled equally according to their workload. Work performance needs to be rewarded with the right form of compensation; (2) the next researcher is expected to be able to increase the population and sample so that they can illustrate the effect of applying remuneration to work engagement; (3) the next researcher is expected to add variables because there are still many factors that can influence work engagement.

\section{REFERENCES}

Alejandro, Orgambídez-Ramos\& Helena de Almeida. 2017. Work Engagement, Social Support and Job Satisfaction in Portuguese Nursing Staff: A Winning Combination.Application Nurse Research, 36, 37-41

Al Hakim, Yusuf Rahman., Mochamad Irfan, Rahayu Mardikaningsih, Ella Anastasya Sinambela. 2019. The Role of Job Relations, Career Development, and Motivation for Employee Job Satisfaction. Management \& Accounting Research Journal, 3(2), 37-45

Bakker, A.B. 2009. Building Engagement in Workplace. Building Engagement, 8-23. 
Bakker, A. B. 2011. An Evidence-based Model ofWork Engagement. Current Directions in Psychological Science, 20(4), 265-269.

Bakker, A. B. \&E. Demerouti. 2007. The Job Demands-Resources Model: State of the Art. Journal of Managerial Psychology, 22(3), 309-328.

Bakker, A. B., S.L. Albrecht \& M.P. Leiter. 2011. Key Questions Regarding Work Engagement. European Journal of Work and Organizational Psychology, 20(1), 4-28.

Calvin, O. Y. 2017. The Impact of Remuneration on Employees' Performance (A Study of Abdul Gusau Polytechnic, Talata-Mafara and State College of Education Maru, Zamfara State). Arabian Journal of Business and Management Review. Nigerian Chapter. 4(2), 34-43.

Cobb, S. 1976. Social Support as a Moderator of Life Stress. Psychosomatic Medicine, 38(5), 300-314.

Cohen, S. \&T.A. Wills. 1985. Stress, Social Support, and the Buffering Hypothesis. Psychological Bulletin, 98(2), 310.

Cride, A. B. 1983. Psychology. Glenview: Scott, Foresman, and Company.

Darmawan, Didit. 2019. Pengantar Manajemen, Surabaya : Revka Prima Media, PT.

Dessler, Gary. 2017. Human Resource Management $15^{\text {th }}$. Harlow Essex: Person Educational.

Drucker, P. 2017. The Effective Executive. Harper Business

Fleming, John H. \& Jim Asplund. 2007. Where Employee Engagement Happens. Gallup Business Journal. 8 November 2007.

Gravetter, F. J. \&L.A.B. Forzano. 2012.Research Methods for the Behavioral Sciences. Canada: Wadsworth.

Gujarati, Damodar \&D.C. Porter. 2013. Dasar-dasar Ekonometrika. Buku 1 dan Buku 2 Edisi 5. Penerjemah: Raden Carlus Mangunsong. Jakarta:Salemba Empat.

Gujarati, Damodar. 2004.Ekonometri Dasar. Terjemahan: Sumarno Zain, Jakarta: Erlangga.

Hair Jr., Joseph F., William C. Black, Barry J. Babin\& Rolph E. Anderson. 2010. Multivariate Data Analysis 7th edition. New York: Pearson Prentice Hall

Hoole, C. \&G. Hotz. 2016. The Impact of a Total Reward System of Work Engagement. SA Journal of Industrial Psychology, 42(1), a1317

Hughes, J. C. \&E. Rog. 2008. Talent Management: A Strategy for Improving Employee Recruitment, Retention and Engagement within Hospitaly Organization. International Journal of Contemporary Hospital Management, 20(7), 743-754

Kahn, W. A. 1990. Psychological Conditions of Personal Engagement and Disengagement at Work. Academy of Management Journal, 33, 692-724

Leavy, R. L. 1983. Social Support and Psychological Disorder: A review. Journal of Community Psychology, 11(1), 3-21.

Lum, Lille, John Kervin, Kathleen Clark, Frank Reid\& Wendy Sola. 1998. Explaining Nursing Turnover Intent : Job Satisfaction, Pay Satisfaction, or Organizational Commitment. Journal of Organizational Behavior, 19, 305-320

Lyons, F.H. \&D. Ben-Ora. 2002. Total Rewards Strategy: The Best Foundation of Pay for Performance. Compensation Benefits Review, 34(2), 34-40

Lysaght, R. M. \&S. Larmour-Trode. 2008. An Exploration of Social Support as a Factor in the Return-to-Work Process. Work, 30(3), 255-266.

Mathis, Robert L. \& John H. Jackson. 2004.Manajemen Sumber Daya Manusia. Jakarta: Salemba Empat

Milkovich,George. \&Jerry Newman.2005.Compensation Eighth Edition.New York: International Ed, Mc Graw Hill.

Mondy, R. Wayne \& Robert M. Noe. 2005. Human Resource Management $9^{\text {th }}$. USA: Prentice Hall.

Obino, Mokaya Samuel \&Maureen Jerotich Kipyegon. 2014. Determinants of Employee Engagement in the Banking Industry inKenya; Case of Cooperative Bank. Journal of Human Resources Management and Labor Studies, (2),2, 187-200

Pora, Antoniode.2011.Remunerasi: KompensasidanBenefit.Tanggerang : Parninta Offset 
Putra, Arif Rachman, Eli Retnowati dan Ella Anastasya Sinambela.2019.Pengaruh Komunikasi Kerja dan Integritas terhadap Kinerja Pegawai.Jurnal Ekonomi Bisnis, 12 (1), 23-34

Ritacco, G., \&S. Suffla. 2012. A Critical Review of Child Maltreatment Indices:Psychometric Properties and Application in the South African Context. ASP, 10(2), 1-15.

Robbins, Stephen P. \&Timothy A. Judge. 2008. Perilaku Organisasi, Edisi 12 Buku 1. Jakarta : Salemba Empat.

Schaufeli, Salanova, V. Gonzales-Roma, \&A.B. Bakker. 2002. The Measurement of Engagement and Burnout: A Two Sample Confirmatory Factor Analytic Approach. Journal of Happiness Studies, 3, 71-92

Schaufeli, W. B. \&A.B. Bakker. 2004. Job Demands, Job Resources and their Relationship with Burnout and Engagement: A Multisample Study. Journal of Organizational Behavior, 25, 293-315.

Schaufeli, W.B. M. Salanova, V. Gonzales-Roma \&A.B. Bakker. 2002. The Measurement of Engagement and Burnout: A two Sample Confirmatory Factor Analytic Approach. Journal of Happiness Studies, 3, 71-92

Schaufeli, W. B. A.B. Bakker \& W.V. Rhenens. 2009. How Changes in Job Demands and Resources Predict Burnout, Work Engagement, and Sickness Absenteeism. Journal of Organizational Behaviour, 30, 893-917.

Schaufeli, W. B. \&A.B. Bakker. 2004. Job Demands, Job Resources and Their Relationship With Burnout and Engagement: A Multisample Study. Journal of Organizational Behavior, 25, 293-315.

Schiemann, A. W. 2009. Alignment Capability Engagement. Jakarta: PPM Management

Schumpeter, J. 1934, Theory of Economic Develompment.Cambrige, mass: Harvard University Press.

Shantz, A., K. Alfes, C. Truss \&E. Soane. 2013. The Role of Employee Engagement in The Relationship between Job Design and Task Performance, Citizenship and Deviant Behaviours. The International Journal of Human Resource Management, 24 (13), 26082627

Shumaker, S. A. \& A. Brownell. 1984. Toward a Theory of Social Support: Closing Conceptual Gaps. Journal of social issues, 40(4), 11-36.

Siddhanta, Abhijit \& DebalinaRoy. 2010. Employee Engagement Engaging The 21st Century Workforce. Asian Journal of Management Research, 170-189

Sikula, Andrew E. 1981.Personal Administration and Human Resources Management.John Wiley \& Sons, Inc

Sinambela, Ella Anastasya., Yusuf Rahman Al Hakim, Moch Irfan. 2019. Pengaruh Kedisiplinan dan Komunikasi Kerja terhadap Kinerja Karyawan. Jurnal Ekonomi, 15(2),308-320

Sinokki, M. 2011. Social Factor at Work and the Health of Employee. Tampere: Juvenes Prints.

Smet, Bart. 1994. Psikologi Kesehatan. Jakarta : PT. Gramedia Widisana Indonesia

Thomas, Kenneth W. 2009. Intrinsic Motivation at Work: What Really Drives Employee Engagement. California : Berrett-Kohler Publishers.

Todaro, M.P \& Stephen C. Smith. 2004.Pembangunan Ekonomi di Dunia Ketiga, Jakarta: Penerbit Erlangga.

Wang, M. T. \&J.S. Eccles. 2012. Social Support Matters: Longitudinal Effects of Social Support on Three Dimensions of School Engagement from Middle to High School. Child Development, 83(3), 877-895

Wayne, S. J., L.M. Shore, W.H. Bommer \&L.E. Tetrick. 2002.The Role of Fair Treatment and Rewards in Perceptions of Organizational Support and Leader-Member Exchange. Journal of Applied Psychology, 87,590-598

Wellins, Bernthal \& Phelps. 2010. Employee Engagement: The Key to Realizing Competitive Advantage. Development Dimensions International, Inc. 
Xanthopoulou, D.,A.B. Bakker, E. Demerouti. \&W.B. Schaufeli. 2009. Work Engagement and Financial Returns: A Diary Study on The Role of Job and Personal Resources. Journal of Occupational and Organizational Psychology. 82. 183-200

Yin, N. 2017. The Influencing Outcomes of Job Engagement: An Interpretation from The Social Exchange Theory. International Journal of Productivity and Performance Management, 67(5), 873-889. 